\title{
Local Company Contribution within Global Value Chain: A Case Study in the Indonesian Footwear Industry
}

\author{
Joklan Goni \\ Prasetiya Mulya Business School, Indonesia \\ joklan.goni@pmbs.ac.id \\ Yohanes Kadarusman \\ Prasetiya Mulya Business School, Indonesia \\ yohanes.kadarusman@pmbs.ac.id
}

\author{
Doi:10.5901/mjss.2015.v6n6s5p444
}

\section{Abstract}

\begin{abstract}
Nowadays, Global Value Chain (GVC) theoretical framework has become a tool can be utilized by country and company to understanding its competitive advantage and position in global economy. By governing companies from various country around the globe into global network relationships, GVC has shown a great value added to the product. The competition among lead firms are built through their ability to gain the most efficient production by sourcing globally, in which involve local company, and Multi National Enterprise's (MNE's) located at developing country. Indonesia is a case of country in which many global lead firms include local company in its value chains. This study aim to understand the value chain governance of Indonesian local company within footwear's industry organized by a global brand and its contribution to development of the local company. This paper revealed that the involvement of local company within Indonesian footwear industry is driven by global lead firm. The first tier suppliers are mostly from Taiwan and only one Indonesia local company on the value chain. While the lead firm undertaking process of design, distribution and marketing, Indonesian local company performing mostly manufacturing activities. However, there is a dynamic transformation in which local company start involving in development stage of the footwear.
\end{abstract}

Keywords: footwear; governance; global value chain; local entrepreneur

\section{Introduction}

Global Value Chain (GVCs) existence not only break the border between countries. GVCs integrate countries through participation in world economy. By having international production sharing increase country contribution opportunities in GVC. Vigorous competition makes large companies find a way to remain competitive in the market. Companies are making efforts to maintain the continuity of their business by sourcing to countries that have low production costs. Large companies doing global sourcing to maintain a global presence to achieve cheaper production costs and focus on core competencies of the company. GVC have fragmented production processes across countries. In the beginning the internationalization of economic activity geographically dispersed without a border, but in its development into a functional integration of these activities (Gereffi, 2008; Gereffi 1999b; Gereffi, 199b). GVCs has increase the interconnectedness of economies and led to a growing specialization in specific activities and stages in value chains, rather than entire industries. (OECD, 2014; ECB, 2014). Unido, in 2003 divides the national production system into three:

\subsection{International Production System}

- Assembly, is a form of industrial subcontracting, in which garment sewing plants are provided with imported inputs for assembly, most commonly in export processing zones (EPZs).

- Original Equipment Manufacturing (OEM), is a form of commercial subcontracting. The supplying firm makes a product according to a design specified by the buyer; the product is sold under the buyer's brand name; the supplier and buyer are separate firms; and the buyer lacks control over distribution.

- Original brand name manufacturing (OBM), is the upgrading by manufacturers from the production expertise of OEM to first the design and then the sale of their own brand products.

Source: Unido, 2003 
In the beginning there are two types of international economic networks, ie buyer-driven and supplier-driven (Gereffi, 2001). This is a factor that determines the role of each actor in the value chain. The role of value chains partners evolve and adapt to the market condition. Gereffi, Humprey and Sturgeon (2003) mapped five different governance structures and footwear industry is the buyer driven and captive governance structure. Footwear industry has the characteristics of the lead firm as the brand owner, do sourcing to countries who are able to carry out production in accordance with the standards specified by the lead firm. The brand owner has a very high bargaining power in the Global Value Chain to determine which producers will get an order for production and exerts close control on the production. Brand owner in footwear consists of 5 players including Nike, Adidas, Reebok, Puma and New Balance which holds 70\% market share (Transparency Market, 2012).

The lead firm begin to look at the Asian countries that have low labor costs for production, including Indonesia. Since the 1990s foreign companies started to invest in Indonesia. It brings positive impact to the development of the shoe industry in Indonesia. One of the brand owners, adidas, sourcing from Indonesia and put Indonesia as third shoes manufacturer after China and Vietnam.

\subsection{Indonesia Footwear Industry}

Indonesia Footwear industry first appeared in 1920s started when an employee of the Dutch quit their jobs and started making his own shoe company, which was known as the embryo of a shoe business in Cibaduyut and known as a cluster of local shoe production reached 4 million pairs per year. Direct investment for the shoe industry began in 1931 at the time of Bata, the Czech company began to set up factories in Kalibata. The oldest company still continues to operate with the number of outlets reach 500 outlets.

The development of the shoe industry in general is dominated by international brands for export destinations such as Nike, adidas and several other international brands. The brand owners apply a very strict rule in the implementation of production activities, including to suppliers. One of the rules is in the form of treatment of workers, which requires companies in Indonesia adhere to strict labor rules. Its regulations include minimum wages in accordance with government regulations, safety equipment and health facilities. Indonesian preferred by brand owner for being able to meet the requirements demanded. Shoe production in Indonesia is famous because it has advantages in quality. Lead firm sourcing to Indonesia for products that have high quality. Indonesia footwear manufacture several types of shoes from athletic shoes to NATO military boots.

Based on data from the Trade Department following several brands that are produced in Indonesia, among others:

\begin{tabular}{|c|c|c|c|c|c|}
\hline Adidas & Cerini & Fly & Michelin & Ananda Singgih & GAP \\
\hline Mod 8 & Chatham & Andre Valentino & Converse & New Era & Nike \\
\hline Sledgers & Hush Puppies & Oakley & Specs & Deichmann & Kappa \\
\hline Osh Kosh & Starmon & Bata & Diadora & Sunly & Beltoni \\
\hline Dockers & Kickers & Pakalolo & Piero & Tomkins & Benetton \\
\hline Eagle & Pierre Cardin & Tommy & Hilfiger & Bertinni & Ecco \\
\hline Lacoste & Reebok & Bubblegummers & Ellesse & Rockport & Uniform \\
\hline Logo & Marie Claire & Fila & Salamander & YongkiKomaladi & Carvil \\
\hline
\end{tabular}

\section{Source: TREDA, 2009}

Since the 1980s, Indonesia Footwear industry began to grow with the support of the government to attract foreign investment. The existence of Footwear Industry in Indonesia strengthened with the establishment of the Indonesian Footwear Association in 1988. At that time the Minister of Industry collects Footwear entrepreneurs in Greater Jakarta, West Java and Central Java to form this association.

Shoe companies in Indonesia spread throughout Indonesia ranging from small companies to companies that produce for export. Until now there are 250 registered industries. Most of the company is centralized in Java, mostly in Jakarta, Bekasi, Tangerang and Surabaya. Quality and good input is one of the key growth footwear industry in Indonesia.

This growth marked by increasing annual export value of Indonesia. With the gross domestic product (GDP) \$ 873 billion in 2013, Indonesia is one of the larger emerging market economies in Southeast Asia with 23\% contribution come from manufacturing (ADB, 2014). Below figure shows sectoral composition of Indonesia's GDP 2013: 


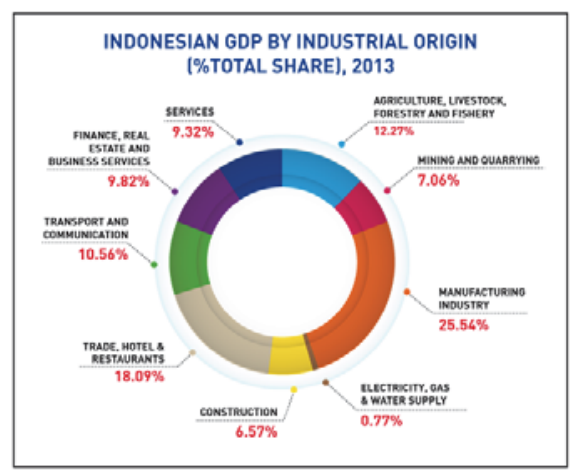

Source: EIBN, 2014

Until now, Indonesia is one of the world's largest exporter of shoes and footwear industries. The ministry of trade data shows footwear record average growth $26.05 \%$ annually and this sector contributed $4.5 \%$ of the total manufacture workforce and employee more than 400,000 direct labors. It estimates revenues from footwear export in 2013 were around $\$ 4$ billion with 79\% contribution from sports footwear (EIBN, 2014). Leather footwear including athletic shoes becomes the largest contributor to exports.

Leading Footwear Exporting Countries (exported value in billion USD)

\begin{tabular}{|c|l|c|c|c|c|c|}
\hline Rank & Country & 2009 & 2010 & 2011 & 2012 & 2013 \\
\hline 1 & China & 28.016 & 36.634 & 41.722 & 46.811 & 50.766 \\
\hline 2 & Italy & 9.165 & 9.868 & 11.610 & 10.823 & 11.785 \\
\hline 3 & Vietnam & 4.152 & 5.230 & 6.718 & 7.515 & 11.555 \\
\hline 4 & Germany & 3.691 & 3.942 & 5.199 & 4.626 & 5.152 \\
\hline 5 & Belgium & 3.514 & 3.683 & 4.157 & 4.306 & 5.131 \\
\hline 6 & Indonesia & 1.736 & 2.502 & 3.302 & 3.525 & 3.860 \\
\hline & of which athletic shoes & 780 & 1.089 & 1.358 & 1.334 & 1.372 \\
\hline
\end{tabular}

Source: GBG adopted from ITC calculations based on UN Comtrade data reported by Governments

Since the early 2000s, competitions among manufacturing countries become very tight. Large companies see China and Vietnam as a country that has a greater potential. These countries are able to compete with the competitiveness of Indonesia with cheap labor and government policies that support the development of the industry. This has an impact to the percentage of orders from Indonesia. Brand owner companies divert some production sourcing from Indonesia to China and Vietnam. But this did not last long. Trends siding with Indonesia back. Firms in Indonesia is slowly regain share in the global market. It is caused by conditions in China which makes the production of goods in the country are more expensive due to China's rising industrial capacity and increasing their value chain. Today, once again the company shoe manufacturer in Indonesia flooded again with orders from outside.

\section{Literature Review}

At first the concept of value chain began in 1970 with the 'commodity chain' (Bair, 2005).Then came the 1994 global concept of commodity chains and global capitalism (Gereffi \& Koerzeniewicz, 1994a). In general, the value chain is defined as the overall activities that provide added value to provide goods and services through the stages in the production, from the design, the input of raw materials to the production, distribution, sales and after-sales service. (Kaplinsky, 2004; Kaplinsky and Morris, 2000; OECD, 2014; European Central Bank, 2014; Banga, 2014). Global Value Chain analysis focuses on the relationship between international companies in the production process, emphasizing the role of the lead firm that does integration is functionally and activities that spread internationally (Gereffi and Kaplinsky, 2001). Activity in the Global Value Chain can be done by one company or divided into multiple companies and locations can be done in one location or spread across the world. Global Value Chain concept covers all phases are used to analyze goods and services ranging from innovation to the process of commercialization (CGGC, 2005). 
Global Value Chain Governance approach was first introduced by Gereffi, 1994, with the understanding governance as 'driving', which later on describe as a producer or buyer driven. (Gereffi \& Korzeniewicz, 1994b)

Producer-driven chains usually an integrated industrial enterprise, large, and transnasional which plays a central role in the chain. Usually a company with capital and technology-intensive, such as automotive companies, aircraft and electrical machinery. Whereas, buyer driven chains are large retail companies, brand name Merchandizer are generally labor intensive, consumer goods industries, such as enterprise clothes, shoes, toys and electronics.

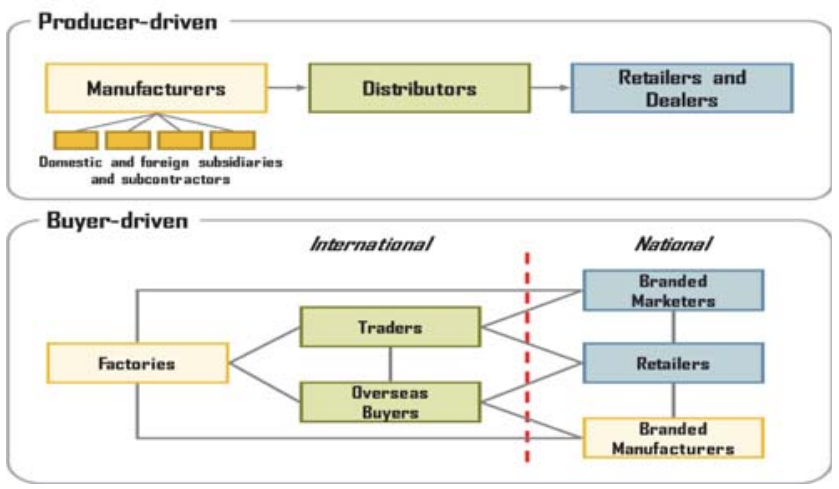

Source: Gereffi (2001)

The role of value chain partners evolve in the value chain impact to the form of governance structure. Gereffi, Humprey and Sturgeon (2003) mapped five different governance structure hierarchy, captive, realtional, modular and market. They also indicated three key factors determine the value chain structure: complexity of the transactions, codifiability of information and capability of suppliers. Footwear is a good example to captive value chains.

To maintain competitiveness, the company strives to achieve global presence, by outsourcing to countries that are capable of production with low cost and focus on the core competencies. As the development of globalization, the first company to import parts or seeking sourcing of production sites, new suppliers are now emerging global suppliers (Sturgeon, 2008). This has obvious implications for the industry, such as the transformation of the functions and relationships between suppliers, a growing number of suppliers are involved in the design, production, create a complete module, while the concentrations of the value of manufacturing engineering, product quality and customer service (Alonso, 2011). There are several studies focus on the GVC governance explored the internal and external structure (Humphrey \& Schmitz, 2004; Schmitz, 2004; Gereffi, Humphrey and Sturgeon, 2003; Gereffi et al., 2005; Tran \& Phillips, 2013, Tijaja \& Faisal, 2014).

On the GVC approach there are comparative GVC analysis (value distribution approached and Input:Output approached) and Comparable studies (traditional and non traditional) (ODI, 2008; Josephine, 2009; Frederick 2014).

Gereffi on OECD 2013 provide key factor affecting developing countries participation in GVC. Some studies also figure out the role of Asian firm in restructuring GVC (Azmeh \& Nadvi, 2014) and how to improve competiveness through cluster (Yusuf \& Trondsen, 2013; Hayat, 2014, Humphrey \& Schmitz, 2002).

Limitation of this research as generally is the case study on a limited basis for generalization and subjective bias (Yin, 2003). The discovery in this research is specific to the situation observed. However, this limitation does not affect the validity and reliability of outcomes, because the purpose of this research is not to generalize but to provide anecdotal evidence and describes the condition of the footwear industry in Indonesia.

\section{Methodology}

Exploratory case study approach used in this research to get the Global Value Chain framework footwear company in Indonesia. Writing at the start by doing a preliminary study of the application of Global Value Chain in the industry in Indonesia. Then made plans to sharpen focus and formulation problems. The study was carried out from November 2014 to April 2015 and consisted of conducting semi-structured interview with adidas manager-Head of Planning footwear (as a lead firm) and senior manager of the factories (as 1st tier supplier) with quantitative data supported by the company's internal data. A total of 5 factories out of 7 factories were conducted to senior manager of the company and 1 senior 
manager of adidas in Indonesia.

To get Footwear Global Value Chain framework, for the lead firm adidas chosen as a case study in the research, because this company is one of the largest footwear company in the context of applying the lead firm Global Value Chain in running the business in Indonesia. For the first tier supplier, Panarub is chosen as the only local company from Indonesia while others are company from Taiwan and Korea.

adidas is a German multinational company founded by Adolf Dassler based in Herzogenaurach. Adidas is the largest producer of sports in Europe, initially producing shoes. Now the company is venturing into the clothing and accessories of various sports ranging from football, handbags, sunglasses and so on. Some brands under the auspices of the adidas Group, among others: adidas, Reebok, TaylorMade (Ashworth) for golf, Rockport. In its annual report adidas 2014, the company recorded sales of euro 14.534 million. Contributions of footwear by $46 \%$, clothing $43 \%$ and $11 \%$ hardware. Footwear sales recorded an increase of $5 \%$. This is a contribution come from increment on sales of running shoes and adidas NEO products that cater to young people. The NEO product itself is one of the products in the product development done in one factory in Indonesia. The company implemented multi-sourcing with suppliers composition of $83 \%$ from Asia, 9\% America 7\% Europe and less than $1 \%$ of Africa. For the production of footwear from Asia, Vietnam occupied the first position with $39 \%$, China down to the second position (27\%), and Indonesia the third position by $23 \%$.

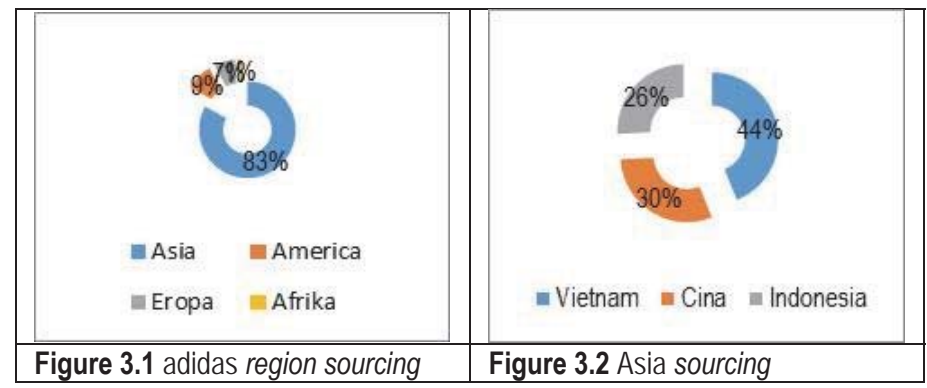

Source: adidas website, 2014

Panarub Industry is local company started in 1968 by Lukas Sasmito, produced rubber sponge and "Lily" plastic sandals. Panarub located in Tangerang with factory area around $20 \mathrm{Ha}$ and 25 lines hi tech production line with around 9,000 employees. The company has 45 years collaboration with adidas, start partnership with adidas brand in 1988 . Afterward, in 1998, Panarub appointed to be adidas football speciality center and 2000 began produced Predator model for World Cup 2000. Company continues expand the business from one factory into additional 2 factories: Panarub Dwi Karya (Benoa) and Panarub Dwi Karya (Cikupa). Company expanded the business to setup a raw material company to support Panarub with technology called SL Rubber, special rubber for adidas football professional shoes since 2012. Panarub produced $1.25-1.4$ milion pairs of shoes per month. Panarub has been a strategic partner for adidas in producing high quality football shoes with techonology innovation which bring the only Local Indonesian company awarded as "The Most Innovative Factory" two year in the row.

\section{Findings}

\subsection{Factory contribution in footwear global value chain}

When adidas first start order from Panarub Industy in Indonesia in 1988, factory only produce shoes as per adidas design. The research and development of the product, design, and marketing come from lead firm while factory only produce the shoes as per requirement. The lead firm involved in most of the aspect included supplier decision for the raw material used in production. They will provide factory with approved supplier list. Below figure show footwear global value chain, where intially factory only involve in the production part.

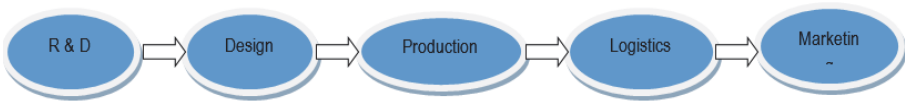

Source: (Stacey Frederic 2014), modified by author. 
In the recent year, factory work closely with adidas in the stages of product development up to the completion of product prototype by supplying the customer designs and engineers with feedback on the product designs. Together, companies develop certain proprietary technologies for the manufacture and components as well as the processing technique. adidas develop their primary supplier by involve factory in the development stages. adidas categorized factory into two, as a production factory or development factory. For the production factory, they will have development center in different location. Usually in China or Vietnam, while for development factory, they will also do production. In Indonesia, Panarub appointed to be adidas football speciality center. In the beginning, design and development come from brand owner (adidas) and factory (Panarub) only produce the shoes.

Since Panarub appointed as adidas football speciality, company continue become a strategic partner for adidas. In 2012, Panarub setup a division: adidas innovation technology (AIT) that responsible to develop a model for adidas football shoes. Adidas place their employee in division to work together with factory to develop new product. Factory send the prototype product to adidas marketing in Germany, then adidas review it by offered shoes to the market (athlete, buyer, lab test and so on.) all over the world. This salesmen sample approximately 5,000 pairs. Then, if buyer agree and commit to buy certain volume, adidas will ask factory capability to produce.

adidas as global buyer also invest in their supplier competence, but they required their supplier to be dominant or exclusive (Gereffi, Humprey and Sturgeon, 2005)

\subsection{Global suppliers}

GVCs framework identify new actor in global economy (e.g., global buyers and global suppliers) (Sturgeon and Gereffi, 2008, Sturgeon at al 2008). UNCTAD 2013 showed due to global financial crisis implied the structural changes in the GVC. One of it consolidation where instead of having number of first tier suppliers, more lead firms prefer to source from larger and competent first tier suppliers. Having global buyers invest in Indonesia stimulate foreign direct investment (OECD 2013b). Back in 2012 for Indonesia, adidas has more than 10 suppliers, now, they only have 4 global suppliers. Initially, some of the factories stand alone deal with adidas but they were push to join with other factory from other countries. adidas want to limit deal with supplier by creating group suppliers. With these global suppliers, adidas will only need to deal with 4 groups, who will allocate the order base on the capability and situation of the order and factory. Below figure showed footwear global value chain:

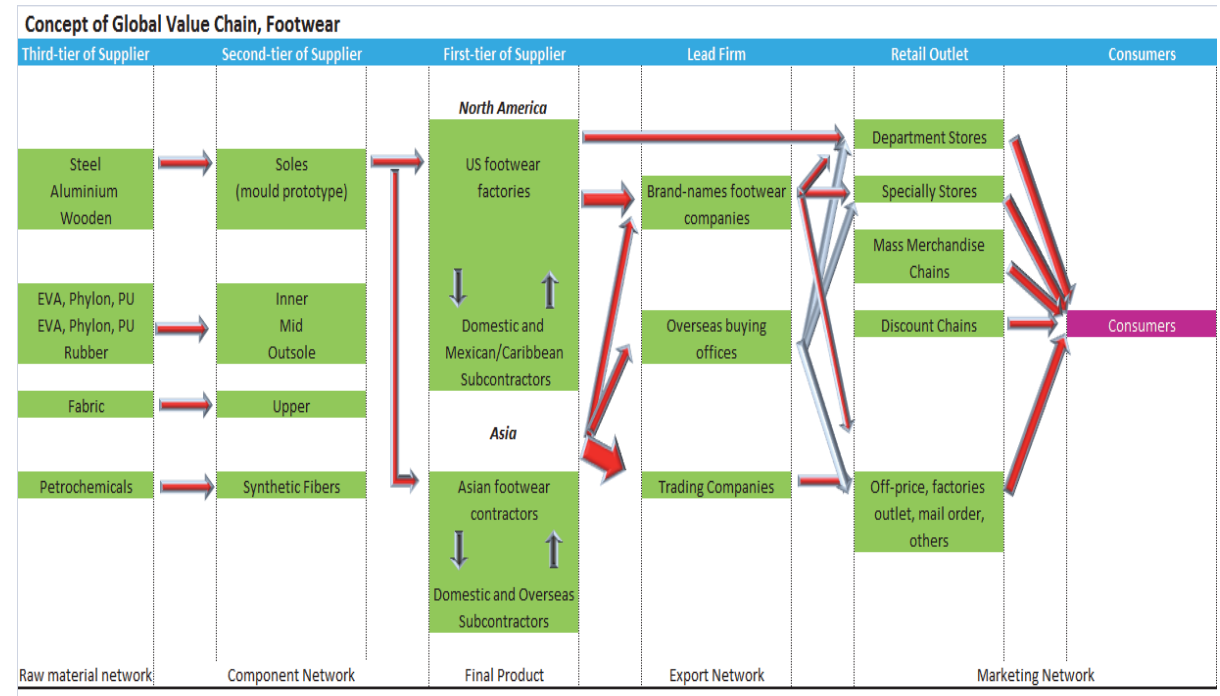

Source: Author, adopted from Gereffi and Memedovic 2003

Figure 4.1 Footwear Global Value Chain

Tabel 4.1 showed adidas four group suppliers: 
Tabel 4.1. adidas Footwear Global Supplier

\begin{tabular}{|l|l|l|l|l|l|}
\hline No & Group Name & Establised & Expand & $\begin{array}{l}\text { Production } \\
\text { country }\end{array}$ & Factory name \\
\hline 1 & $\begin{array}{l}\text { Pou Chen Group/ } \\
\text { Yu Yuen }\end{array}$ & Taiwan, 1969 & & China & $\begin{array}{l}\text { Dong Guan Pou Chen Footwear Co Ltd } \\
\text { Zhong San Sanxiang Pou Yuen Footwear Co. Ltd } \\
\text { Yu Yuen (Anfu) Footwear Co. Ltd }\end{array}$ \\
\hline & & & 1994 & Vietnam & $\begin{array}{l}\text { Pou Yuen Vietnam Cmpy Limited } \\
\text { Pouyuen Vietnam }\end{array}$ \\
\hline 2 & $\begin{array}{l}\text { Shyang shin Bao Group/ } \\
\text { Shyang way Group }\end{array}$ & Taiwan & 1992 & Indonesia & $\begin{array}{l}\text { Pou Chen (PT. Nikomas Gemilang) } \\
\text { Glostar Indonesia } \\
\text { Glostar Indonesia 2 }\end{array}$ \\
\hline & & & & Indonesia & Shyang Yao Fung (SY2) \\
\hline 3 & Ching Luh Group & Taiwan & 2007 & Indonesia & $\begin{array}{l}\text { Ching Luh Indonesia } \\
\text { Ching Luh Indonesia 2 }\end{array}$ \\
\hline & & & 1989 & China & $\begin{array}{l}\text { Ching Luh Shoes Co., Ltd } \\
\text { Lian Jiang Ching Luh Shoes Co., Ltd }\end{array}$ \\
\hline 4 & Evervan Group & Chinese \& Indonesia & 1988 & Indonesia & PT Panarub Industry \\
\hline
\end{tabular}

Source: Authors adopted from adidas annual report 2014

In Indonesia, 1st tier supplier for adidas come from seven factories with four groups.

Tabel 4.2 showed footwear factories in Indonesia and their locations:

Tabel 4.2. Footwear factories in Indonesia

\begin{tabular}{|l|l|l|l|}
\hline No & Company name & Group & Location \\
\hline 1 & PT Panarub Industry (adidas) & Evervan, Chinese \& Indonesian & Tangerang \\
\hline 2 & PT Nikomas Gemilang (adidas) & Pou Chen owned by Taiwanese & Serang \\
\hline 3 & PT Glo star (reebok) & Pou Chen owned by Taiwanese & Sukabumi \\
\hline 4 & PT Glo star 2 (adidas) & Pou Chen owned by Taiwanese & Sukabumi \\
\hline 5 & PT Parkland World Indonesia & No group owned by Korean & Serang \\
\hline 6 & PT Ching Luh Indonesia & Ching Luh owned by Taiwanese & Tangerang \\
\hline 7 & PT Shyang Yao Fung & Shyang Shin Bao by Taiwanese & Tangerang \\
\hline
\end{tabular}

\section{Source: Authors}

There is one factory with no group. Out of this seven factories, Panarub is the only factory which owned by local Indonesian. The rest of the factories are a direct foreign investment from Taiwan and Korean. Government regulation on the local content, impact the adidas strategic sourcing. Factory in Indonesia has reached $60-70 \%$ of the raw material are sourcing locally. The regulation stimulate investor to setup a production facility for material required for shoes a second tier supplier. Factory must use approved supplier list from adidas, however factory can propose 2nd tier supplier. By having supplier near the factory location will help to improve lead time. adidas team will visit the factory to assess the 2nd tier suppliers. Base on adidas subcontractor factory list, following are the suppliers list in Indonesia: 


\begin{tabular}{|l|l|l|l|}
\hline No & Supplier Name & Location & Materials \\
\hline 1 & Namkwang Tech Indonesia & Serang & Metal - korea \\
\hline 2 & PT Anugerah Cipta Mould Indonesia & Tangerang & moulding machine - korean \\
\hline 3 & PT Baiksan Indonesia & Tangerang & Leather - korea \\
\hline 4 & PT Citra Bina Maju Jaya & Tangerang & Embroidery \\
\hline 5 & PT Dong A Decal & Jakarta & Printing-korea \\
\hline 6 & PT Evertech Plastic & Serang & Packaging -taiwan \\
\hline 7 & PT Framas Plastic Technology & Bekasi & Sole-germany \\
\hline 8 & PT Hanjin Insole Indonesia & Karawang & Sole - korea \\
\hline 9 & PT Korin Technomic & Tangerang & Mould - japan \\
\hline 10 & PT Korye Polymer Jaya (Polymer Utama) & Tangerang & Sole \\
\hline 11 & PT Sinar Utama Jaya Abadi (SUJA) & Tangerang & Fabricated rubber product \\
\hline 12 & PT Sung Shin Indonesia & Bekasi & Shoe manufacture- korea \\
\hline
\end{tabular}

Source: Authors, partially adopted from adidas website 2014

Most of the 2nd tier suppliers are a foreign direct investment from Taiwan and Korea.

\subsection{Factory expansion (1st tier supplier)}

Shifting order from China to Indonesia due to dumping policy and Vietnam current situation has positively impact the 1st tier supplier in Indonesia to expand their production capacity. With the current challenges ie labor wage increment, factory start looking for alternative production facility location. Most of the factory start build their production facility in Central Java, ie Panarub will start their production in Brebes on June 2015. There are some challenges on the labor skill, thus to anticipate this situation, Panarub plan to allocate production for standard product with less complexity for factory in Central Java. On the other side, adidas as brand owner also aware that their past experience moving production facility around the world base on the low labor wage will have the limit. Ten years ago they closing down their production facility in Singapore and Malaysia. Base on their past experince they start encourage 1st tier supplier to start consider automation on the production facility. adidas conduct a workshop or each factory to share their production facility and Panarub is one of the factory who start utilize automation. Due to their location limitation, Panarub implement robotic system which help them to manage their labor cost, reducing almost thirty percent of the labor in past two year.

\section{Conclusions and Further Research}

Based on the qualitative research with adidas footwear factory (1st tier) in Indonesia, adidas pursue the global supplier. These suppliers dominate by foreign direct investment from Taiwan and Korea. Out of 7 factory only 1 factory owned by local Indonesian. According to the study, due to requirement on local content and lead time also stimulate another foreign direct investment for 2nd tier supplier in Indonesia.

The study also showed there has been change on the contribution of the supplier, from only doing "sewing", now, involved in development stage of the product. Some of the factory is appointed as development factory.

Shifting order from China and Vietnam to Indonesia, positively impact the production capacity which required supplier to increase their production volume. Goverment policy on the labor wage, required factory to expand their production facility to other location in Indonesia with lower labor wage.

This study only deal with the exposure of some adidas footwear 1st tier suppliers in Indonesia to find their contribution in adidas footwear global value chain. It is interesting to know how these supplier can get the sustainability as a strategic supplier through technology innovation and expand their role in the global value chain. Also interesting to learn how to increase local enterpreneur and involve SME's participation as a 2nd tier suppliers in footwear global value chain (Branziskas, 2013; Rolly, 2014; Alonso, 2012 ).

\section{References}

Alonso, Jorge., Oscar F Contreras and Jorge Carrilo(2012). Local entrepreneurship within Global Value Chain: A Case Study in Mexican Automotive Industry (2012). World Development, Vol. 40, No. 5, pp. 1013-1023

Aprisindo. (2012). Indonesia Footwear Industry Development. Presented for 3rd EU-Indonesia Business Dialogue (EIBD).

Azmeh, Shamel, Khadlid Nadvi. (2014). Asian Firm and the Restructuring of global value chain.International Business Review, Vol.23, 
pp. 708-717

Branziskas, Sigitas and Julisu Beinoravicius. (2013). SMEs and integration driving factors to regional and global value chains. Procedia - Social and Behavioral Sciences, vol. 110, pp 1033-1041

Bloomberg. Bloomberg.com. Retrieved from Bloomberg on 31 April 2015 from http://www.bloomberg.com/research/stocks /private/snapshot.asp?privcapld=5689362

Bair, J., \& Dussel, E. (2006). Global commodity chains and endogenous growth: Export dynamism and development in Mexico and Honduras.World Development, 34(2), 203-221.

Ching Luh Website. (2015). chingluh.com. Retrieved 30 April 2015, from http://www.chingluh.com/website/en/Develop.php

CGGC. (2005). Global Value Chain Initiatives. Retrieved April 31, 2015, from www.globalvaluechains.org

ECB. (2014). Mapping Global Value Chain. European Central Bank: Working Paper Series.

EIBN. (2014). Textile \& Footwear. EIBN sector reports

Faisal, M. and Julia Tijaja. (2014). Industrial Policy in Indonesia: A Global Value Chain Perspective. ADB Economics Working Paper Series, No.411

Frederick, Stacey. (2014). Combining the Global Value Chain and global I-O approached. International conference on the Measurement of International Trade and Economic Globalization.

Gereffi, G. (2001). Shifting Governance Structures in Global Commodity Chain. American Behavioral Scientist, Vol. 44, pp.1616-1637

Gereffi, G. (2011). Global value chain and international competition. The Antitrust Bulletin, Vol. 56, No. 1

Gereffi, G. (1999a). International trade and industrial upgrading in the apparel commodity chain.Journal of International Economics, 48(1), 37-70.

Gereffi, G. (1999b). A Commodity Chain Framework for Analyzing Global Industries.

Gereffi, G., \& Kaplinsky, R. (2001). The value of value chains: Spreading the gains from globalization. Special issue.IDS Bulletin, 32(3), $1-12$

Gereffi, G., Humphrey, J., Kaplinsky, R., \& Sturgeon, T. J. (2001). Introduction: Globalisation, value chains and development. IDS Bulletin, 32, 1-8.

Gereffi, G., Humphrey, J., \& Sturgeon, T. J. (2005). The governance of global value chains. Review of International Political Economy, 12, 78-104.

Gereffi, G., \& Korzeniewicz, M. (1994a).Commodity chains and global capitalism. Westport, CT: Praeger Publishers.

Gereffi, G., \& Korzeniewicz, M. (1994b). The organization of buyer-driven global commodity chains. In G. Gereffi, \& M. Korzeniewicz (Eds.),Commodity chains and global capitalism(pp. 95-122). Westport, CT: Praeger Publishers

Hayat, Syed A. (2014). Indonesia Global Expansion: A Case Study. International Journal of Global Business, Vol. 7, 9-33

Humphrey, J., \& Schmitz, H. (2002). How does insertion in global value chains affect upgrading in industrial clusters?.Regional Studies, 36(9), 1017-1027.

Humphrey, J., \& Schmitz, H. (2004). Chain governance and upgrading: Taking stock. In H. Schmitz (Ed.), Local enterprises in the global economy issues of governance and upgrading (pp. 349-382). England:Edward Elgar.

Kaplinsky, R. (2004). Spreading the gains from globalization: What can be learned from value-chain analysis?.Problems of Economic Transition, 47, 74-115.

Kaplinsky, R. and Mike Morris. (2000). A Handbook for Value Chain Research

Lang, Josephine C.2009. Cluster Competitiveness: The six negative forces. Journal of Business Management, Vol.15 no 1.

ODI. (2008). A'New' Approach to Global Value Chain Analysis. Overseas Development Institute.

OECD. (2007). Staying Competitive in the Global Economy: Moving up the Value Chain. Paris, France: Organization for Economic Development and Co-operation (OECD).

OECD. (2008). Enhancing the Role of SMEs in Global Value Chains. Paris, France: Organization for Economic Development and Cooperation (OECD).

OECD. (2013a). Interconnected Economies: Benefiting from Global Value Chains. Paris, France:Organisation for Economic Cooperation and Development (OECD) Publishing

OECD. (2013b). Connecting local producer in developing countries to regional and global value chain - update. OECD Trade Policy Paper, No. 160

OECD, WTO \& World Bank. (2014). Global Value Chain: Challenges, Opportunities, and Implication of Policy. G20 Trade Minister Meeting.

Panarub Industry. (2015). Panarub.co.id. Retrieved on 30 April 2015, from http://www.panarub.co.id/profile/milestone

Pou Chen Group. (2015). pouchen.com. Retrieved on 30 April 2015 from http://www.pouchen.com/index.php/en/about/milestone

Rolly, Purnomo R. (2014). Country Presentation. Global value chain in Indonesia: Experiences, Policies and Strategies. Asian Development Bank, Singapore 8 May

Banga, Rasmi. (2014). Linking into GVC is not sufficient: Do you export domestic value added contents?. Journal of Economic Integration, Vol. 29 No. 2, pp. 267-297

Rugman, A.M, D.S.K Lim and C.H Oh. (2012). The regional and global competitiveness of multinational firms. Academy of Marketing Science, 40:218-235

Schmeisser, Bjoern. (2013). A Systematic Review of Literature on Offshoring of Value Chain Activities. Journal of International Management, Vol. 19, pp. 390-406

Schmitz, H. (2004). Globalized localities: Introduction. In H. Schmitz (Ed.), Local enterprises in the global economy issues of governance 
and upgrading. England: Edward Elgar.

Sturgeon, T. (2013). Global Value Chains and Economic Globalization - Towards a New Measurement Framework: Eurostat.

Sturgeon, T. J., Biesebroeck, J. V., \& Gereffi, G. (2008).Value chains, networks, and clusters: Reframing the global automotive industry. Doshisha University working paper series, 08-02. Institute for Technology, Enterprise and Competitiveness

Sturgeon, T., \& Memedovic, O. (2011). Mapping Global Value Chains: Intermediate Goods Trade and Structural Change in the World Economy UNIDO Development Policy and Strategic Research Branch Working Paper 05/2010. Vienna, Austria: United Nations Industrial Development Organization (UNIDO).

Sturgeon, T. and Gary Gereffi. (2008). The Challenge of Global Value Chains: Why integrative trade requires new thinking and new data. Prepared for Industry Canada.

Tran, Nhuong and Michael Phillips. (2013). Governance of Global Value Chais in Response to Food Safety and Certification Standards: The Case of Shrimp from Vietnam. World Development, Vol. 45, pp. 325-336

Transparency Market Research. (2012). transparencymarketresearch.com. Retrieved 29 April 2015, from http://www.transparencymarketresearch.com/footwear-market.html.

TREDA. (2009). Indonesia Footwear: Step to the world. Trade Research and Development Agency, Handbook of Commodity Profile.

UNCTAD. (2013). World Investment Report 2013: Global Value Chains: Investment and Trade for Development World Investment Report. Geneva, Switzerland.

UNIDO. (2003). The Global Apparel Value Chain: What Prospects for Upgrading by Developing Countries?. Vienna, Austria United Nations Industrial Development Organization (UNIDO). Sectoral Studies Series

UNIDO. (2011). Industrial Value Chain Diagnostics: An Integrated Tool. Vienna, Austria:United Nations Industrial Development Organization (UNIDO).

Yin, Robert K. (2003). Case Study Research:Design and Methods. 3rd edition. Applied Social Research Method Series, Vol. 5

Yue Yuen. (2015). Yueyuen.com. Retrieved on 30 April 2015, from http://www.yueyuen.com/index.php/en/equipment

Yusuf, Muhammad, and Torbjorn Trondsen. (2013). Improving Indonesia's competitiveness: Innovation, value chains and cluster bases for realising the huge potential of marine and fisheries. International Journal of Organizational Innovation, Vol.6. 